\title{
PENINGKATAN KAPASITAS GUDANG DENGAN PERANCANGAN LAYOUT MENGGUNAKAN METODE CLASS-BASED STORAGE
}

\author{
Heldy Juliana*), Naniek Utami Handayani*) $^{*}$ \\ Program Studi Teknik Industri, Fakultas Teknik,Universitas Diponegoro \\ Jl. Prof. H. Soedarto, SH. Semarang 50239
}

(Received: March 23, 2016 / Accepted: June 14, 2016)

\begin{abstract}
Abstrak
Gudang adalah suatu tempat penyimpanan untuk semua barang-barang hasil produksi maupun penjualan. Fungsinya sebagai tempat penyimpanan memiliki peranan yang sangat vital. Oleh sebab itu diperlukan adanya pengaturan yang tepat dan cepat dalam penggunaan ruang gudang. CV.MDP-Semarang merupakan industri kemasan karton yang berlokasi di Semarang. Tingginya tingkat penggunaan gudang di perusahaan ini membuat effisiensi waktu dan ruang menjadi penting. Dari hasil pengamatan, CV. MDP-Semarang belum memiliki tata letak penyimpanan yang baik. Hal ini terlihat dari cara penyimpanan bahan baku di gudang yang belum mengikuti kaidah tata letak gudang. Pada gudang bahan baku, karton diletakkan secara acak sehingga menyulitkan pencarian, kapasitas gudang bahan baku saat ini dikeluhkan tidak mencukupi kebutuhan. Parameter tata letak gudang bahan baku yang baik adalah dipenuhinya ruang secara maksimal dan pemenuhan terhadap permintaan bahan baku yang lebih cepat. Pada penelitian ini, metode class-based storage dan penggunaan rak, memisahkan karton berdasarkan jenis karton di gudang bahan baku mampu memberikan peningkatan kapasitas gudang. Dengan rancangan tata letak gudang bahan baku usulan dapat meningkatkan kapasitas gudang, sehingga mampu memberikan ruang kosong untuk 64.000 pieces karton.
\end{abstract}

Kata kunci: tata letak; kapasitas gudang; class-based storage

\begin{abstract}
Warehouse is a storage for all the goods of production and sales. Its function as a storage has a very vital role. Therefore it is necessary to have the proper regulations in the use of warehouse space. CV.MDPSemarang is the carton packaging industry located in Semarang. The high level of the activity in the warehouse make time and space efficiency becomes important. From the observation, CV. MDP-Semarang do not yet have good storage layout. It is shown from raw material inventory in storage that are not following the principle of good storage layout. In the raw materials storage carton are placed randomly, so it makes the operator difficult to find the goods and the storage become out of capacity to fulfill demand. The good parameters for good storage are the optimal utility and the capapbility to fulfill raw material demands faster. In this paper, class-based storage method and shelf are used to separate carton based on type of carton in raw material storage in order to improve storage capacity. By proposes the design raw material storage layout, the company should be able to increase storage capacity, thus, it will be able to give space for 640.000 pieces of carton.
\end{abstract}

Keywords: layout; storage capacity;class-based storage

\footnotetext{
${ }^{*}$ Penulis Korespondensi. email: heldyjuliana@student.undip.ac.id, naniekh@ft.undip.ac.id
} 


\section{Pendahuluan}

Tata letak pabrik termasuk aspek utama dalam dunia industri karena berkaitan erat dengan cara pengaturan fasilitas-fasilitas pabrik. Pengaturan tata letak pabrik yang optimal akan berkontribusi terhadap kelacancaran seluruh operasi pabrik (Zhenyuan dkk, 2011). Artinya tata letak pabrik yang baik dapat menempatkan berbagai fasilitas dan peralatan fisik secara teratur sehingga mendukung pekerjaan berjalan secara produktif (Zhenyuan dkk, 2011). Beberapa cara dapat dilakukan untuk mencapai kelancaran proses produksi, salah satunya melalui sistem penyimpanan material yang baik. Sebagai contoh, keberadaan gudang bahan baku dalam pabrik akan menjamin ketersediaan bahan baku pada waktu yang tepat dan jumlah yang tepat sehingga mempengaruhi kelancaran proses produksi sampai menghasilkan barang akhir dan diterima oleh konsumen. Oleh karena itu, sistem pergudangan pada dasarnya berfungsi penting dalam kelancaran rantai pasok (Goetschalckx, 2009).

Kinerja sistem penyimpanan barang bergantung pada beberapa karakteristik internal dan eksternal. Karakteristik internal meliputi: (1) kapasitas penyimpanan; (2) kemudahan akses ke lokasi penyimpanan; (3) kompleksitas struktur internal; dan (4) dan tingkat teknologi informasi. Sedangkan karateristik eksternal seperti jenis produk, jumlah produk, jumlah persediaan untuk disimpan, dan tipe aliran barang masuk dan keluar. Besarnya variansi jenis dan jumlah produk yang dipesan dapat menimbulkan perbedaan kebutuhan bahan baku antara satu pesanan dengan pesanan lainnya. Kondisi ketidakpastian ini memicu timbulnya masalah lain, yaitu lamanya kontrak pemesanan bisa disepakati, seperti tidak sesuainya desain pesanan yang dihasilkan dengan yang diminta pelanggan dan terjadinya keterlambatan dalam pemenuhan pesanan (Azmi et al, 2010).

Tantangan inilah yang saat ini sedang dihadapi oleh CV. MDP. CV. MDP merupakan industri kemasan karton yang berlokasi di Kawasan Industri Candi Semarang. Pertumbuhan industri pangan, farmasi, dan barang-barang kebutuhan konsumen yang cukup pesat telah mendorong terjadinya peningkatan permintaan terhadap industri kemasan. Sebagian besar produk kemasan karton merupakan pesanan yang didesain secara khusus untuk konsumen tertentu sehingga perusahaan beroperasi berdasarkan pesanan (make-toorder/MTO). Produksi yang bersifat make to order memberikan tingkat ketidakpastian dan kompleksitas perencanaan produksi yang tinggi. Ketidakpastian dan kompleksitas ini antara lain berasal dari besarnya variasi bentuk dan desain kemasan karton, jumlah yang dipesan, waktu kedatangan pesanan dan waktu penyelesaian pesanan yang diharapkan pelanggan (Azmi et al, 2010). Karena kondisi tersebut, perusahaan menerapkan kegiatan penempatan barang dengan kebijakan.

Jurnal Teknik Industri, Vol. XI, No. 2, Mei 2016 randomized storage, yaitu karton ditempatkan secara acak tanpa aturan tertentu. Hal ini menyebabkan proses peletakkan karton di sembarang tempat, sehingga kapasitas yang dimiliki gudang belum dimanfaatkan secara optimal dan menyebabkan terjadinya penurunan kapasitas gudang sebenarnya. Contohnya bahan baku karton yang frekuensinya kedatangannya 1 kali dalam seminggu ditempatkan pada area yang berjarak 40,25 meter dari pintu gudang, sedangkan pada area yang terdekat dari pintu yaitu berjarak 6,75 meter hanya diisi oleh bahan baku yang frekuensi kedatangannya hanya 1 kali dalam sebulan. Berdasarkan fakta tersebut perlu dilakukan perancangan kebijakan penyimpanan dan perancangan tata letak gudang agar menjadi lebih baik.

Penelitian ini dimaksudkan untuk merancang perbaikan tata letak gudang bahan baku dengan menggunakan metode class-based storage pada CV. MDP dengan tujuan peningkatan utilisasi kapasitas gudang dan percepatan pemenuhan pemintaan karton. Metode class-based storage digunakan dalam perbaikan tata letak gudang bahan baku di CV. MDP dengan pertimbangan karton yang disimpan di gudang bahan baku memiliki karakteristik tertentu yang mampu membedakan antara karton yang satu dengan lainnya. Sehingga perlu dilakukan penelitian lebih lanjut mengenai pemilahan dan penyimpan bahan baku tersebut. adalah:

Adapun batasan masalah pada penelitian ini

a. Setiap pesanan berisi beberapa item dengan berbagai jumlah.

b. Layout gudang terdiri dari satu blok dan satulorong, dan ruang penyimpanan disesuaikan.

c. Data yang digunakan merupakan data produksi yang berlangsung saat penelitian yaitu pada bulan Januari-Maret 2015.

d. Tidak melakukan perhitungan biaya perbaikan tata letak.

e. Tidak melakukan perubahan terhadap sistem produksi maupun urutan proses produksi.

f. Tidak ada penambahan atau pengurangan fasilitas atau departemen selama penelitian berlangsung.

g. Tidak ada penambahan jenis produk baru selama penelitian berlangsung.

\section{Tinjauan Pustaka}

Gudang merupakan tempat penyimpanan material yang diperlukan untuk proses produksi, material tersebut akan terus disimpan hingga siap diproses sesuai dengan jadwal produksi atau order konsumen. Adapun tujuan dari kegiatan penyimpanan material adalah :

a. Untuk menyeimbangkan antara kemampuan produksi dengan demand konsumen

b. Untuk memberikan suatu customer service yang spesifik 
c. Untuk menambah nilai pada produk

Aktivitas yang umumnya dilakukan berkaitan dengan penyimpanan material dalam gudang, adalah Receiving, Prepacking, Put-away, Storage, Order picking, Packaging, Sortation and accumulation, Packing and Shipping (Tompkins \& Tanchoco, 1996). Dalam perancangan tata letak gudang terdapat beberapa prinsip yang umum dijadikan sebagai acuan, yaitu: Popularity, Similarity, Size, Characteristics dan Space utilization. Beberapa karakteristik komponen yang penting yaitu: Perishable materials (komponen yang mudah rusak), Oddly shaped and crushable items (komponen bentuk khusus dan mudah rusak), Hazarduous materials (komponen berbahaya), Security items (komponen dengan pengamanan khusus) dan Compatibility (kecocokan/kesesuaian).

Penempatan barang adalah kegiatan yang berhubungan dengan berdasarkan apa suatu barang ditempatkan dalam gudang. Kebijakan penempatan barang ini berdampak pada waktu transportasi yang dibutuhkan dan proses pencarian atau penelusuran barang. Berikut ini adalah jenis-jenis kebijakan penempatan barang:

\section{a. Random storage}

Yaitu penempatan barang berdasarkan tempat yang paling dekat dengan lokasi input barang, implikasi kebijakan ini adalah waktu pencarian barang lebih lama. Random storage memerlukan sistem informasi yang baik, umumnya cara ini dilakukan pada sistem AS/RS (Automated Storage/Retrievel System).

b. Fixed storage atau dedicated storage

Aplikasi kebijakan yang menempatkan satu jenis bahan atau material di tempat yang khusus hanya untuk bahan atau material tersebut. Kebijakan ini akan mengurangi waktu dalam pencarian barang, namun ruang yang dibutuhkan menjadi kurang efisien karena ruang kosong untuk satu bahan atau material tidak diperbolehkan untuk ditempati bahan atau material lainnya. c. Class-based storage

Yaitu penempatan bahan atau material berdasarkan atas kesamaan suatu jenis bahan atau material kedalam suatu kelompok. Kelompok ini nantinya akan ditempatkan pada suatu lokasi khusus pada gudang. Kesamaan bahan atau material pada suatu kelompok, bisa dalam bentuk kesamaan jenis item atau kesamaan pada suatu daftar pemesanan konsumen.

\section{d. Shared storage}

Penempatan beberapa bahan atau material dalam satu area yang dikhususkan untuk bahan atau material tersebut. Kebijakan ini mengurangi jumlah kebutuhan luas gudang dan mampu peningkatkan utilisasi area penempatan persediaan.

\section{Metodologi Penelitian}

Pada penelitian ini dibutuhkan data tata letak gudang bahan baku existing, karakteristik karton, data jadwal pemesanan dan permintaan karton, serta aliran bahan di gudang bahan baku. Data tata letak gudang bahan baku digunakan untuk mengetahui tata letak saat ini meliputi dimensi pallet yang digunakan, gang, peralatan material handling yang digunakan, dimensi mesin, serta kebijakan yang diterapkan dalam penempatan karton. Data karakteristik karton adalah data mengenai ciri-ciri yang dimiliki tiap karton yang disimpan. Data ini digunakan untuk penentuan dalam penempatan dengan metode class based storage. Data jadwal dan jumlah pemesanan dan permintaan barang digunakan untuk mengetahui karton jumlah dan permintaan karton di gudang yang juga dapat mempengaruhi kebijakan penempatan barang. Data aliran bahan digunakan untuk mengetahui aliran karton sejak datang dari supplier hingga dikeluarkan untuk diproduksi. Keempat data yang digunakan dalam dalam perancangan tata letak gudang bahan baku diperoleh melalui pengamatan dan pengukuran langsung di lapangan, serta berdasarkan data historis yang dimiliki perusahaan.

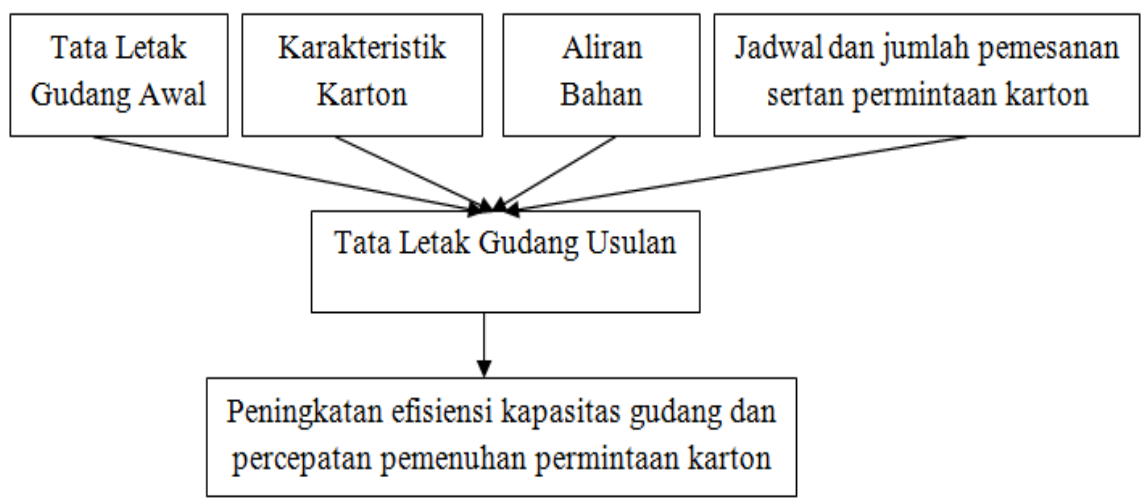

Gambar 1. Model Konseptual

Jurnal Teknik Industri, Vol. XI, No. 2, Mei 2016 


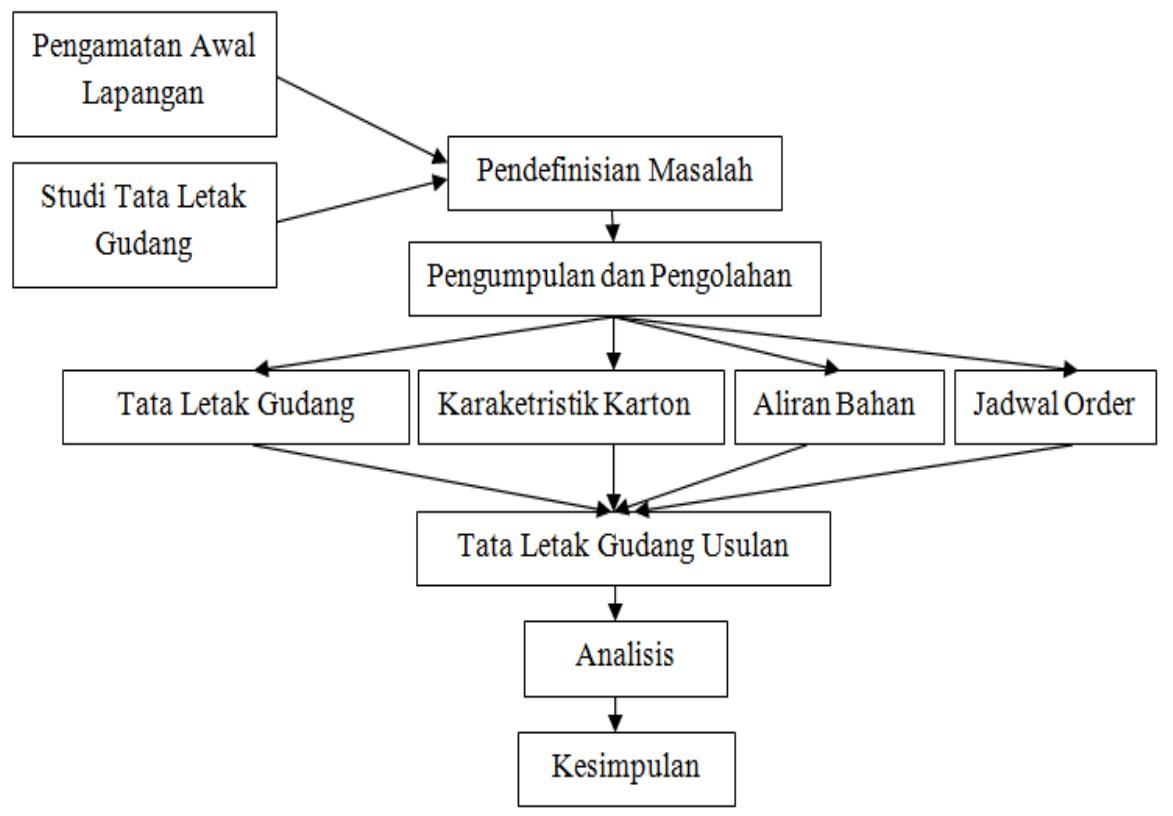

Gambar 2. Tahapan Penelitian

Adapun tahapan dan urutan proses penelitian yang dilakukan sebagai berikut: pertama tahap pendahuluan, yaitu pengamatan awal mengenai permasalahan utama di lapangan hingga diperoleh pendefinisian awal mengenai permasalahan yang diangkat. Kedua adalah tahap melakukan studi tentang hal-hal yang terkait dengan tata letak gudang. Ketiga adalah tahap pengumpulan dan pengolahan data. Pada tahap ini dilakukan pengumpulan data yang mendukung dalam proses penelitian mengenai tata letak gudang bahan baku, diantaranya data tata letak gudang existing meliputi luas dan tinggi gudang, alat-alat yang terdapat di gudang bahan baku beserta dimensinyaPada pengolahan data dilakukan perancangan kebijakan berdasarkan prinsip perancangan tata letak gudang, analisis kebijakan yang akan digunakan dalam penempatan karton pada tata letak gudang usulan. Tahap keempat adalah analisa terhadap tata letak gudang bahan baku usulan yang telah diperoleh dengan kebijakan penempatan yang baru berdasarkan metode class based storage serta tata letak fasilitas yang ada di gudang bahan baku. Terakhir adalah tahap Kesimpulan dan Saran, pada tahap ini akan ditarik kesimpulan yang merujuk kembali kepada tujuan dari penelitian ini. Selain itu, akan diberikan saran untuk perbaikan dan pengembangan lebih lanjut terhadap penelitian sejenis.

\section{Hasil dan Pembahasan}

Berikut ini adalah layout gudang bahan baku saat ini: Ukuran dari gudang bahan baku CV. MDPSemarang adalah $45,6 \mathrm{~m} \times 22,6 \mathrm{~m} \times 3 \mathrm{~m}$. Proses keluar masuk bahan baku melalui sebuah pintu berukuran $2 \mathrm{~m}$ x 2,5 m. Selain itu, untuk menjamin kelancaran kegiatan pergudangan dalam gudang bahan baku terdapat beberapa fasilitas. Fasilitas tersebut adalah sebagai berikut:

a. Tempat penimbangan

Pada tempat ini merupakan lokasi penumpukan karton yang dikirim oleh supplier. Pada lokasi ini terdapat alat timbang dengan dimensi $1,2 \mathrm{~m} \times 0,5$ $\mathrm{m} \times 1,42 \mathrm{~m}$.

b. Inspeksi

Setelah karton ditimbang dan sesuai dengan nota yang dikirim. karton selanjutnya diinspeksi oleh operator.

c. Penyimpanan karton

Tempat penyimpanan karton dibagi menjadi beberapa bagian yaitu karton yang belum diinspeksi, lolos inspeksi, dan karton yang tidak lolos inspeksi. Lokasi penyimpanan tersebar tanpa adanya ketentuan tertentu

d. Administrasi

Bagian administrasi merupakan bagian yang mengelola administrasi di gudang seperti data keluar dan masuknya karton di gudang bahan baku.

e. Proses Pembuatan Kemasan Karton

Proses produksi pada industri ini secara garis besar terdiri dari dua tahapan, yaitu proses pembuatan karton bergelombang (corrugating) dan proses konversi karton menjadi produk kemasan (converting). Aktivitas yang termasuk proses konversi adalah proses printing, proses die cutting, proses gluing/stitching berserta tahapan-tahapan 
persiapan (set up) sebelum, di tengah proses atau setelah proses konversi berlangsung.

Diagram aliran bahan baku baku di dalam gudang saat memenuhi order pengiriman ke lantai produksi meliputi: karton yang datang dari supplier selanjutnya ditimbang untuk memastikan antara berat serta jenis yang ada di nota dengan yang dikirmkan; karton selanjutnya disimpan di sembarang tempat yang tersedia untuk menunggu giliran pengecekan; karton dicek dengan mesin inspeksi untuk melihat mutu dari karton yang dikirmkan. Jika karton dianggap cacat dan harus dikembalikan, maka karton akan diletakkan di bagian karton tidak lolos inspeksi. Jika karton dianggap baik maka disimpan pada tempat penyimpanan karton yang kosong.

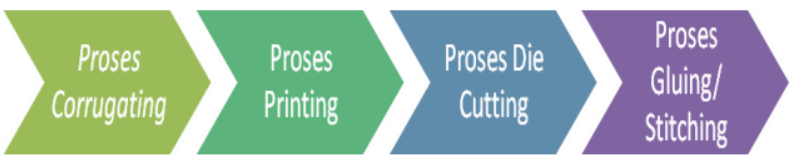

Gambar 3. Tahapan Proses Pembuatan Kemasan Karton (CV. MDP, 2015)

\section{Karakteristik Karton}

Karton yang disimpan digudang bahan baku CV. MDP-Semarang secara garis besar terdapat 2 jenis karton yaitu karton lipat (folding carton), dan karton gelombang (corrugated box). Karton-karton tersebut disimpan di dalam gudang dalam sebuah lot. Setiap rak memiliki berat sebesar $25 \mathrm{~kg}$ dan berukuran $50 \mathrm{~cm}$ x 30 $\mathrm{cm}$ x $90 \mathrm{~cm}$. Dalam penyimpanannya karton lipat dan karton gelombang tidak memiliki perlakuan khusus. Kedua jenis karton tersebut diletakkan di sembarang tempat yang tersedia.

Untuk mendukung kegiatan aliran bahan di gudang bahan baku terdapat beberapa alat material handling. Alat material handling yang digunakan yaitu sebagai berikut: a. 1 buah Kereta dorong dengan dimensi $2 \mathrm{~m} \mathrm{x} 1 \mathrm{~m} \mathrm{x}$ $80 \mathrm{~cm}$.

b. 1 buah Handclift dengan dimensi $1 \mathrm{~m} \mathrm{x} 70 \mathrm{~cm} \times 80$ $\mathrm{cm}$.

c. Operator yaitu adalah semua tenaga kerja yang bekerja digudang. Manusia digunakan jika karton yang dibawa tidak terlalu banyak atau kereta dorong dan handclift sedang digunakan.

\section{Jadwal Pemasukan dan Pengeluaran Karton}

Setiap harinya karton selalu datang dari supplier dan juga keluar untuk diproduksi. Pengiriman dari supplier dan pengiriman ke produksi berlangsung setiap hari dan setiap waktu. Data persediaan karton saat ini dan data keluar dan masuk karton di gudang bahan baku CV. MDP-Semarang setiap bulan dapat dilihat pada Tabel 1 dan Tabel 2.

Selanjutnya, data pada Tabel 1 akan digunakan untuk penentuan kapasitas gudang saat ini, sedangkan data pada Tabel 2 akan digunakan untuk penentuan letak karton karena karton dengan permintaan tertinggi harus diletakkan dekat dengan pintu keluar masuk gudang. Tabel 1, menunjukan jumlah persediaan bahan baku untuk periode Juni-Juli, sementara tabel 2 adalah data pemakaian bahan baku selama periode Juni-Juli. Dari data tersebut dapat terlihat status persediaan bahan baku selama periode Juni-Juli

\section{Kebutuhan Produk}

Produk yang diproduksi oleh CV. MDP-Semarang melewati beberapa tahapan proses. Pada beberapa tahapan proses, terdapat scrap yang tentunya akan menambah jumlah produk yang harus disiapkan. Data berikut ini akan menentukan kebutuhan produk yang harus disiapkan dari awal produksi, sehingga dapat memenuhi permintaan. Jumlah yang diminta adalah permintaan dari produk yang harus dipenuhi, sedangkan jumlah yang disiapkan diperoleh dengan rumus sebagai berikut (Wignjosoebroto, 2003):

Jumlah yang harus disiapkan $=\frac{\text { jumlah yang diminta }}{1-\text { 9lscrap }}$

Tabel 1. Persediaan Bahan Baku CV. MDP-Semarang Periode Juni-Juli (dalam satuan lot)*

\begin{tabular}{cccc}
\hline No & Kode Produk & Jenis Sheet & Persediaan \\
\hline 1 & $0215-0000$ & Duplex dan B-flute & 3 \\
2 & $0201-0000$ & B-flute & 1 \\
3 & $0206-0000$ & Duplex & 2 \\
4 & $0428-0027$ & Art carton & 1 \\
5 & $0428 / 0427$ & C-flute & 5 \\
6 & $0232-0000$ & Duplex dan e-flute & 1 \\
7 & $0620-0000$ & BC-flute & 0 \\
\hline
\end{tabular}

*1 lot terdiri dari 40 pieces karton 
Tabel 2. Pemakaian Bahan Baku BC-Flute Periode Juni-Juli

\begin{tabular}{clc}
\hline Jenis & \multicolumn{1}{c}{ Nama } & Pemakaian \\
\hline \multirow{3}{*}{ BC-flute } & Kotak radio/tape & 14 \\
& Kardus susu & 9 \\
& Kardus aqua gelas & 24 \\
\hline
\end{tabular}

Tabel 3. Jumlah Kebutuhan Gudang

\begin{tabular}{lc}
\hline \multicolumn{1}{c}{ Nama } & Kebutuhan \\
\hline Duplex dan B-flute & 3 \\
B-flute & 1 \\
Duplex & 2 \\
Art carton & 1 \\
C-flute & 4 \\
Duplex dan e-flute & 1 \\
BC-flute v.1 & 10 \\
BC-flute v.2 & 5 \\
BC-flute v.3 & 55 \\
\hline
\end{tabular}

\section{Tata Letak Gudang Bahan Baku}

Saat ini karton yang diletakkan di gudang bahan baku diletakkan secara acak dengan menempati ruang kosong yang tersedia. Sehingga jarak yang ditempuh untuk mengambil karton apapun jenisnya pada kondisi saat ini adalah dari pintu keluar masuk ke seluruh lokasi penyimpanan karton lolos inspeksi yaitu $827,48 \mathrm{~m}^{2}$. Jarak tempuh pada setiap jenis karton adalah sama karena petugas gudang bahan baku diasumsikan tidak mengetahui karton yang dicari, sehingga harus mencari pada gudang keseluruhan.

Dengan menggunakan rumusan tersebut dapat diperloleh jumlah kebutuhan produk. Dengan diketahui jumlah kebutuhan produk dapat diketahui berapa jumlah material yang harus disiapkan dan akhirnya akan diperoleh jumlah kebutuhan gudang yang tertera pada tabel 3 ke seluruh lokasi penyimpanan karton lolos inspeksi yaitu $827,48 \mathrm{~m}^{2}$. Jarak tempuh pada setiap jenis karton adalah sama karena petugas gudang bahan baku diasumsikan tidak mengetahui karton yang dicari, sehingga harus mencari pada gudang keseluruhan.

Dalam penentuan kebutuhan ruang digunakan jumlah pembelian, pengembalian, dan saldo awal dari tiap jenis karton. Hal ini dikarenakan karton harus disimpan dalam jumlah yang besar mengingat jarak dari pemesanan dari supplier sampai karton dikirimkan kurang lebih selama 2 bulan. Selanjutnya dari tiap periode dirata-ratakan untuk menentukan kapasitas yang dibutuhkan dalam gudang. Kapasitas yang dibutuhkan diperoleh dengan menghitung jumlah lot yang harus disimpan.

Total keseluruhan jumlah lot yang harus disimpan adalah 8.930 lot yang terdiri dari karton lipat dan karton gelombang (data selengkapnya terlampir).

\section{Tata Letak Gudang Usulan}

Dalam perancangan tata letak gudang usulan metode penyimpanan yang digunakan adalah class based storage yang dikombinasikan dengan randomized storage. Metode class based storage akan mengelompokkan karton berdasarkan jenis karton yaitu karton lipat dan karton gelombang. Selanjutnya dari tiap jenis karton tersebut dipecah lagi menjadi beberapa jenis karton kembali. Dari lokasi penyimpanan tiap jenis karton lalu ditetapkan metode randomized storage, artinya karton dengan jenis yang telah ditetapkan bebas ditempatkan dimana saja, tanpa ada pemberian ruang yang lebih khusus.

Dalam urutan peletakan jenis karton diurutkan berdasarkan rata-rata permintaan dari tiap jenis karton. Jenis karton yang paling tinggi permintannya diletakkan paling dekat dengan pintu keluar masuk. Area pada gudang bahan baku selanjutnya dibagi menjadi 6 area yaitu area penyimpanan karton lolos inspeksi, area penyimpanan karton sebelum diinspeksi, area karton yang harus dikembalikan, area penimbangan, area administrasi, dan area mesin produksi. Sedangkan lokasi printing, dipindahkan ke area cutting gelaran karena masih terdapatnya ruang kosong yang tersedia.

Setiap area penyimpanan disusun menjadi 2 tingkat dengan tinggi penyimpanan maksimal untuk tingkat 1 adalah 1,5 m sedangkan untuk tingkat 2 adalah $1,2 \mathrm{~m}$. Kapasitas setiap area penyimpanan diperoleh dengan memperhitungkan dimensi dari pallet dari karton yang diletakkan secara horizontal.

\footnotetext{
$>$ Area penyimpanan $1=(1,75 / 0,9) \times(45,6 / 0,5) \mathrm{x}$ $(2,7 / 0,3)=1.642$ lot

$>$ Area penyimpanan $2=(1,75 / 0,9) \times(40 / 0,5) \times$ $(2,7 / 0,3)=1.440$ lot
} 
$>$ Area penyimpanan $3=(1,75 / 0,9) \times(40 / 0,5) \mathrm{x}$ $(2,7 / 0,3)=1.440 \mathrm{lot}$

$>$ Area penyimpanan $4=(1,75 / 0,9) \times(40 / 0,5) \mathrm{x}$ $(2,7 / 0,3)=1.440 \mathrm{lot}$

$>$ Area penyimpanan $5=(1,75 / 0,9) \times(40 / 0,5) \times$ $(2,7 / 0,3)=1.440$ lot

$>$ Area penyimpanan $6=(1,75 / 0,9) \times(40 / 0,5) \times$ $(2,7 / 0,3)=1.440$ lot

$>$ Area penyimpanan $7=(1,75 / 0,9) \times(34 / 0,5) \mathrm{x}$ $(2,7 / 0,3)=1.224 \mathrm{lot}$

$>$ Area penyimpanan $8=(1,75 / 0,9) \times(15 / 0,5) \times$ $(2,7 / 0,3)=540$ lot

$>$ Area sebelum inspeksi $=(1,75 / 0,9) \times(6 / 0,5) \times$ $(2,7 / 0,3)=200$ lot

$>$ Area retur $=(2,7 / 0,9) \times(25 / 0,5) \times 3=450$ lot

Gang antar rak diberikan selebar 1,15 m. Hal ini berdasarkan lebar maksimal dari alat material handling yaitu $1 \mathrm{~m}$, karena pada proses penyimpanan sebagian besar menggunakan kereta dorong atau handclift. Sedangkan pada proses pengambilan karton sebagian besar menggunakan tenaga manusia. Berdasarkan datadata tersebut dapat diketahui rancangan tata letak gudang usulan seperti gambar 3 pada lampiran. Dalam penyimpanan karton prosedur yang dilakukan adalah sebagai berikut:

a. Karton disimpan secara berurut menurut Tabel 4 dalam tiap rak, dengan urutan pertama diletakkan paling depan dan dilanjutkan hingga ke belakang.

b. Tiap jenis karton diisi dengan cara memenuhi ruang hingga keatas, setelah terpenuhi selanjutnya mengisi kembali dari bawah. Setiap jenis karton diberi sekat untuk membedakan pengelompokan dengan jenis lainnya.

Tabel 4. Kapasitas Area Penyimpanan Karton

\begin{tabular}{cc}
\hline Area Penyimpanan & Kapasitas \\
\hline 1 & 1.642 \\
2 & 1.440 \\
3 & 1.440 \\
4 & 1.440 \\
5 & 1.440 \\
6 & 1.440 \\
7 & 1.224 \\
8 & 540 \\
Area sebelum inspeksi & 200 \\
Area retur & 450 \\
\hline
\end{tabular}

\section{Analisis}

Dalam perancangan tata letak fasilitas dibutuhkan luas lantai yang sesuai untuk proses produksi karton kemasan. Kebutuhan ruangan turut memperhatikan allowance yang dibutuhkan oleh tiap fasilitas seperti allowance operator, material, dan material handling. Allowance-allowance tersebut tentunya juga Jurnal Teknik Industri, Vol. XI, No. 2, Mei 2016 membutuhkan sejumlah area untuk menampungnya.

Dengan perancangan blok area penyimpanan memudahkan operator dalam menyusun karton berdasarkan jenis karton yaitu karton lipat dan karton gelombang.. Selain itu, untuk memudahkan identifikasi pengelompokkan karton. Selanjutnya dari tiap jenis karton tersebut dipecah lagi menjadi beberapa jenis karton kembali yang ditempatkan dengan metode randomized storage. Kelebihannya adalah fleksibel karena ruang kosong untuk satu material diperbolehkan untuk ditempati material lainnya.

Ketentuan layout yang mengatur bahwa jenis karton yang paling tinggi permintannya harus diletakkan berdekatan dengan pintu keluar masuk mengakibatkan kapasitas penyimpanan gudang meningkat. Total karton harus disimpan disimpan adalah 8.766 lot dan kapasitas awal gudang untuk menampung karton sebesar 8.930 lot $(102 \%)$. Efisiensi dalam penggunaan kapasitas gudang dihitung sebesar $102 \%$ (8.930 : 8.766). Dengan perancangan tata letak luas gudang bahan baku, kapasitas meningkat menjadi 11.256 lot, maka efisiensi baru dihitung sebesar 128\% (11.256: 8.766) atau dengan kata lain efisiensi meningkat 22\% (128\% - 102\%).

Penghematan ini dihasilkan dari pemanfaatan area vertikal gudang untuk menyimpan komponen-komponen yang diletakkan diatas rak. Sehingga, dapat disimpulkan bahwa dengan perancangan tata letak gudang bahan baku yang baru dapat memennuhi kebutuhan karton yang disimpan. Kelebihan area dapat dimanfaatkan untuk mengatasi pemesanan yang berlebih, melihat lamanya lead time dalam pemesanan karton.

\section{Kesimpulan}

Berdasarkan penelitian yang telah dilakukan, dapat disimpulkan bahwa pada tata letak gudang usulan digunakan area penyimpanan dengan lot sehingga dapat menambah kapasitas gudang. Dengan penggunaan rak ini terdapat kapasitas cadangan gudang yaitu sebanyak 1.600 lot. Dengan kebijakan penempatan class-based storage, karton dikelompokkan berdasarkan jenisnya dan diurutkan menurut jumlah permintaannya. Karton dengan permintaan terbesar diletakkan paling dekat dengan pintu keluar masuk. Sehingga mempercepat pencarian karton karean tidak perlu mencari ke seluruh gudang, melainkan cukup mencari pada rak dimana jenis karton ditempatkan.

\section{Daftar Pustaka}

Azmi, N., Jamaran, I., Arkeman Y., dan Mangunwidjaja, D. (2012). Perancangan Model Penerimaan dan Evaluasi Pesanan pada Industri Kemasan Karton yang Berbasiskan Make To Order. Bogor: Institut Pertanian Bogor.

Dwiyanto, A. (2008). Perancangan Tata Letak Gudang Barang Jadi di PT. Toa Galva Industries. Semarang: Institut Teknologi Semarang. 
Goetschalckx, M., Gu, J., dan McGinnis, L. F. (2009). Research on warehouse design and performance evaluation: A comprehensive review. European Journal of Operational Research, 203, 539 549.

Hidayat, N. P. A. (2012). Perancangan Tata Letak Gudang dengan Metoda Class-Based Storage Studi Kasus CV. SG Bandung. Jurnal Al-Azhar Indonesia Seri Sains dan Teknologi, 1(3), 105115.
Tompkins, J. A., White, J. A., dan Tanchoco, J. M. (1996). Facilities Planning (Fourth ed.). USA: John Wiley \& Sons.

Wignjosoebroto, S. (2003). Tata Letak Pabrik dan Pemindahan Bahan. Surabaya: Guna Widya.

Zhenyuan, J., Xiaohong, L., Wang, W., Defeng, J., dan Lijun, W. (2011). Design and Implementation of Lean Facility Layout System of Production Line. International Journal of Industrial Engineering, 18(5): 260-269. 


\section{Lampiran}

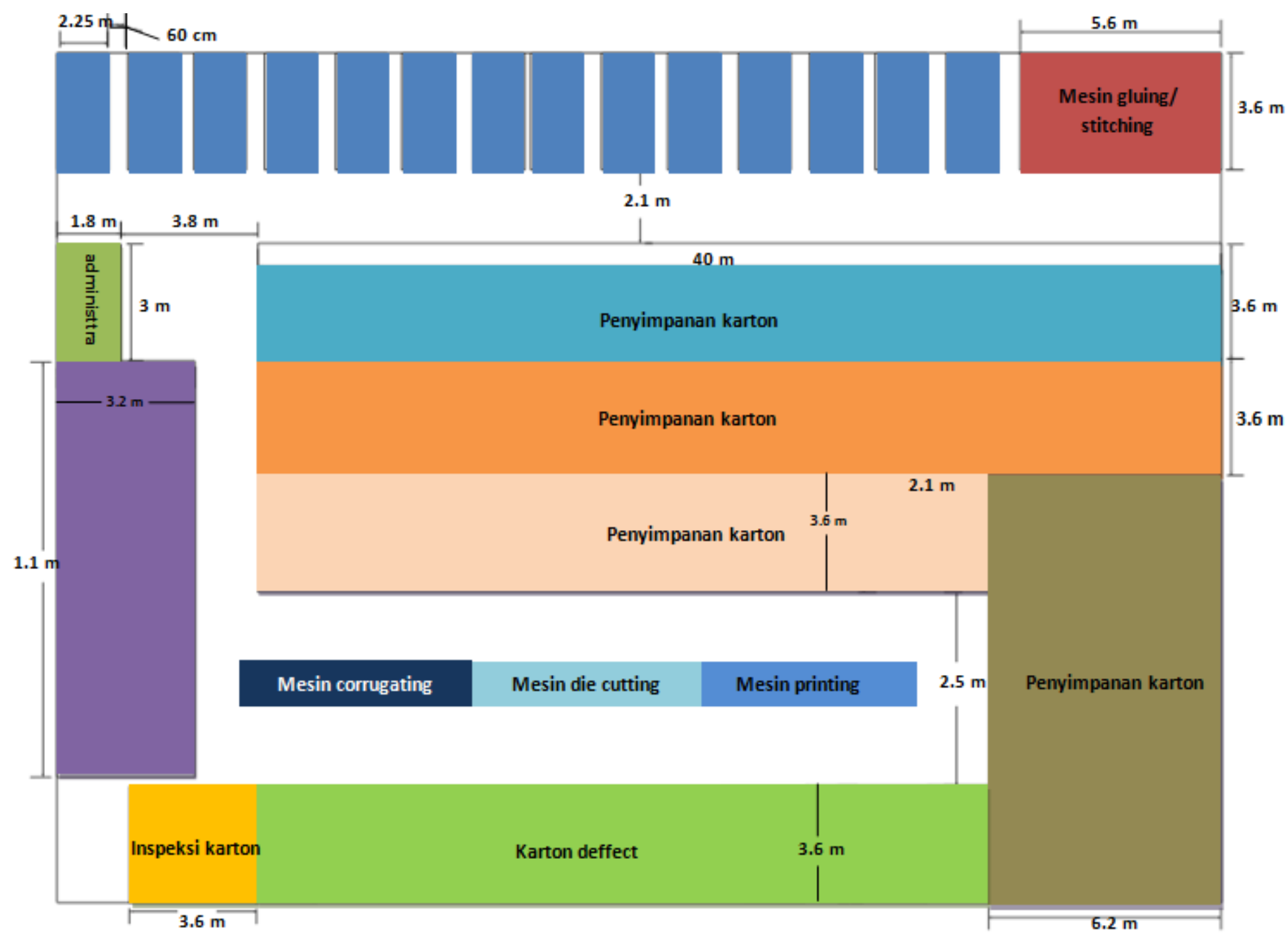

Gambar 4. Tata Letak Gudang Karton 


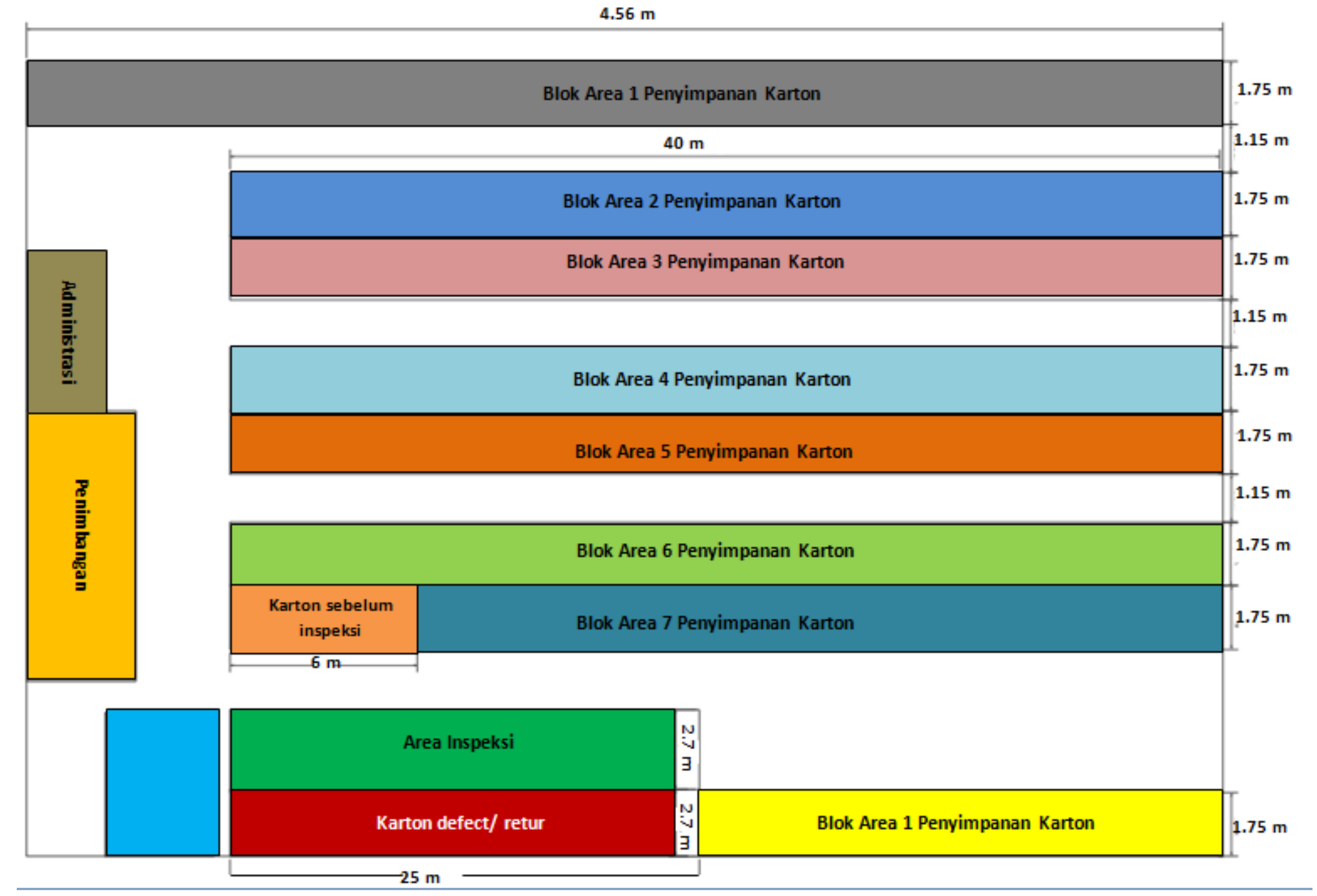

Gambar 5. Tata Letak Gudang Usulan 